\title{
Effect of Antitumor for Neem Leaf Extract and Nimbolide on Ehrlich Ascites Carcinoma Cells in Mice
}

\author{
Faten Zahran Mohamed, Mohamed Abd El-Hakim Basuni, ${ }^{2}$ Noha Gamal Haikel ${ }^{3}$ \\ 'Department of Chemistry, Biochemistry Division, Faculty of science, Zagazig university, Cairo, Egypt \\ ${ }^{2}$ Biochemistry Children Hospital Faculty of Medicine, Mansoura University, Cairo, Egypt \\ ${ }^{3}$ Department of Chemistry, Faculty of science, Cairo university, Cairo, Egypt
}

Disclose and conflicts of interest: none to be declared by all authors

\section{ABSTRACT}

Introduction: Azadirachta Lalandica (neem) has traditionally been used for several years. Some impressive therapeutic qualities have been obtained. The objective of the study is to identify antimicrobial agents, antioxidant activities in ENE and Nimbolide, lemon extracts in leaves and Indica flowers and Azadirachta. Also, to study the side effects of neem ethanol extract and nempolide fraction on different organs (liver / kidney).

Materials and Methods: We evaluated the effect of neembolide leaves and neem ethanol (ENLE) on longevity and levels of monolidealdehyde, nitric oxide, catalase, clotathione peroxidase, caspase 3 and cytokrome. The study showed an effect on Alanine Aminotransferase (ALT), Aspartate Aminotransferase (AST), Total Protein (T.P), Albumin, Bilirubin, Urea and Creatinine. Results: The extracted ethane and nempolid leaves showed a significant increase in shelf life. In addition, decreased malondialdehyde and nitric oxide were significantly increased in catalase enzymes, glucathione peroxidase enzymes, caspase activity 3 , and cytochrome c.

Conclusion: thus, Nimbolide and ENLE may reduce the lipid peroxide level due to their antioxidant effect and enhance the process of extracting the neem leaf extract. The nebulide did not show any side effects on liver and kidneys. Also, as demonstrated, Nympolid and ENLE have significant protection for both liver and kidney dissection.

Keywords: Cancer; Antioxidant; Ehrlich ascites carcinoma cells; Nimbolide

\section{Introduction}

Despite considerable advances in understanding biology and pharmacy, cancer is one of the most serious problems for human health. The usual treatment methods are considered to be beneficial individually in certain cases, and when combined with other treatments, they are a more efficient treatment for tumors. The results of the analysis of several therapeutic drugs and their sources show that more than $60 \%$ of the approved drugs are derived from natural compounds. ${ }^{1}$ Scientists believe that antioxidants are substances that may protect cells from becoming cancerous by installing unstable molecules, known as free radicals. It is also believed to contribute to diseases such as cancer. To date, different studies have shown the relationship between antioxidants and cancer. The differences between the findings of some people within the scientific community led to questioning the effectiveness of the use of antioxidant supplements when trying to prevent or combat cancer., ${ }^{2,3}$ In recent years, a great effort has been made toward identifying substances that occur naturally and that can protect against oxidative stress. ${ }^{4}$ Natural antioxidants contain a wide range of biochemical activities, including inhibition of ROS generation, direct or indirect detection of free radicals, alteration of reduction potentials and intracellular oxidation. ${ }^{5}$ Plants are a natural source for the production of a large number of biologically active chemical components in a multilayered and selectively efficient manner. A different class of biologically active compounds has been isolated and distinguished since the mid-nineteenth century. Much of these are used as the active ingredients of modern medicine, or as the lead compounds for new drugs discovery. Many plantderived drugs, rich in phenolics, alkaloids, flavonoids, ribenoids, tannins, etc., are used in the treatment of various diseases. ${ }^{6}$ Azadirachta indica (Neem), a mother of all therapeutic plants, has been used on a large scale for several decades and is still used for ritual and medical purposesDue to its ease of availability and low cost, many people have been able to benefit from this dynamic plant. Studies have been performed on a wide range of leaves until the bark to explore their therapeutic potential. Phytochemical compounds such as azadrachine, nimbidine, nimbin, nimbinin, nimbidine, nimboldate, nimbidic acid, nimbidine and sodium nemptite derived from neem plant have a variety of medicinal effects such as antipyretic agents, contraceptives, anti-bacterial antioxidants effect and many more.?

\section{Materials and Methods}

\section{Plant Materials and Extraction}

The Azadirakata indica leaves were collected from Al-Qanater Charitable, Egypt in 2012 and were identified and proven by the Herbalist Department of 
Botany, Cairo University. The leaves were sandwiched and grinded to powder using a grinding machine. Neem extract prepared by. ${ }^{8}$ The extract was extracted in a normal saline solution to obtain a final concentration. ${ }^{9}$ Extraction of nimbolide was synthesis according to. ${ }^{10}$

\section{Animals}

120 Swiss white mice aged 22 to $25 \mathrm{~g}$ were purchased from the Animal House Colony at the National Research Center, Dokki, Giza, Egypt. Animals were kept at the Experimental Animal House at the Faculty of Science, Zagazig University. The mice were kept in an appropriate environment of temperature, humidity and light, fed on a standard commercial diet and ad libitum tap.

\section{Ehrlich Ascites Carcinoma Cells}

EAC cells were initially supplied from the National Cancer Institute, Cairo, Egypt (only for the first transplantation), and maintained in female Swiss albino mice through serial intraperitoneal (I.P.) inoculation of $0.2 \mathrm{ml}$ of freshly drawn ascites fluid (diluted to 1:5 saline solution), each inoculum contained $\sim 2.5 \times 106$ cells. This process was repeated every 10 days for keeping the strain available throughout the present study. ${ }^{11}$

\section{Neem Extract and Nimbolide Identification}

A- $\mathrm{H}^{1}$ NMR, $\mathrm{C}^{13}$ NMR and Mass spectrum: The $\mathrm{H}^{1}$ NMR and $C^{13}$ NMR spectra were recorded with Jeol instrument (Japan), at 270 and $125 \mathrm{MHz}$ respectively. The Mass spectrum was recorded on a GCMS-QP 1000 ex spectra mass spectrometer operating at $70 \mathrm{ev}$. The analyses were carried by the Microanalytical Data Unit at the National Research Center, Giza, Egypt according to. ${ }^{9}$ B- High Performance Liquid Chromatography HPLC High Performance Liquid Chromatography (HPLC) analysis of ENLE and nimbolide was performed at the National Research Center, Giza, Egypt according to. ${ }^{10}$

Toxicity study and dose response curve Approximate LD50 of neem extract was determined according to the method. ${ }^{12}$ Dose response curve for ENLE in mice was determined according to the method. ${ }^{13}$ Studies performed for determination of the most effective dose on tumor volume and count.The LD50 value of a single i.p. administration of nimbolide to adult female was $225 \mathrm{mg} / \mathrm{kg}$ body wt according to. ${ }^{14}$ One tenth of LD50 was used in this work is the most effective dose of nimbolide was first reported by. ${ }^{15}$

\section{Experimental Design}

Ninety adult female albino mice were divided into six groups (each one contained 15 mice). Group I: (Negative control): 15 mice injected i.p. with sterile saline solution $(0.9 \mathrm{NaCl})$ for 9 days. Group II: (Positive control): 15 mice were injected i.p. with EAC cells $2.5 \times 106$ cells $/ 0.2 \mathrm{ml}$ once for 9 days. Group III: Therapeutic group of ENLE: 15 mice were injected with EAC cells $2.5 \times 106$ cells $/ 0.2 \mathrm{ml}$ before inoculation with $5 \mathrm{mg} / \mathrm{Kg}$ body.wt ENLE treatment day by day for 9 days. Group IV: Preventive group of ENLE: ice were injected with ENLE treatment before inoculation with EAC cells $2.5 \times 106$ cells $/ 0.2 \mathrm{ml}$. Mice received $5 \mathrm{mg} / \mathrm{Kg}$ b.w ENLE treatments day by day for 9 days. Group V: Therapeutic group of Nimbolide: 15 mice were injected i.p. with EAC $2.5 \times 106$ cells $/ 0.2 \mathrm{ml}$ before inoculation once with $22.5 \mathrm{mg}$ Nimbolide cckg b.w according to15 for 9 days. Group VI: Preventive group of Nimbolide: 15 mice were injected with $22.5 \mathrm{mg}$ Nimbolide / kg b.w once then were injected with EAC cells $2.5 \times 106$ cells/0.2 $\mathrm{ml}$ for 9 days.

\section{Sampling and Preparation Blood Sampling}

At the end of experimental period, Plasma was collected on anticoagulant (EDTA) by centrifuging blood at 3000 r.p.m. for 10 minutes to carry out antioxidant assays (MDA, NO, Catalase and GPx). Serum was collected into a plain tube for determination of liver function tests (ALT, AST, T.P, albumin and bilirubin) and kidney function tests (Urea and Creatinine).

\section{Tissue Sampling}

EAC cells were harvested from the peritoneal cavity of each rat and placed in an isotonic saline solution to evaluate the anti-cell activity (Caspase-3 and Cytochrome c). The mouse was dissected and the liver and kidney tissues were removed and placed in a $10 \%$ formal saline solution, embedded in paraffin, cut and stained with hematoxylin and iodine $(\mathrm{H} \& \mathrm{E})$ to evaluate tissues.

\section{Viability and Life Span Prolongation}

The validity of the EAC cells was previewed by the Blue Tribal exclusion method, ${ }^{16}$ The total and viable cells (untreated) were calculated at $40 \times$ magnification; the number of cells / $\mathrm{ml}$ was calculated in the groups studied. Lifetime determination was performed according to the method described by. ${ }^{17}$

\section{Biochemical Investigations}

Malondialdehyde (MDA) levels were analyzed and measured according to ${ }_{1}^{18}$ Nitric Oxide (NO) was determined by ${ }_{19}^{19}$ catalase enzyme activity (CT) was estimated according to ${ }^{20}$ and Glutathione Peroxidase GPx activity was measured according to. ${ }^{21}$ The activity of caspase- 3 was determined the colorimetric caspase-3 kit according to the method of, ${ }^{22}$ and Cytochrome $\mathrm{c}$ was determined according to the method. ${ }^{23}$ Total Protein was measured by, ${ }^{24}$ Albumin according to ${ }^{25}$ Alanine Aminotransferase (ALT) and Aminotransferase (AST) were determined according to ${ }^{26}$ Serum bilirubin was determined according to. ${ }^{27}$ Urea was measured by ${ }^{28}$ and creatinine was measured according to. ${ }^{29}$ 


\section{Histopathological Examination}

The flat parts of the liver and kidneys were examined on the surface of a clean microscope slide according to. ${ }^{30}$

\section{Statistical Analysis}

All statistical analyzes were conducted by SPSS 14.0 for Social Sciences, SPSS Inc. And were statistically significant at $p<0.05$ on two sides. The numerical data was expressed as $\pm \mathrm{SD}$. The levels of markers were analyzed by ANOVA but the Mann Whitney test was used for independent comparisons groups. ${ }^{31}$

\section{Results}

\section{Total Extract and Nimbolide Yield}

Neem leaves powder $(0.5 \mathrm{Kg})$ after undergoing extraction, yielded $15.8 \mathrm{~g}$ of Ethanolic Neem Leaf Extract (Thick green paste) and other $(0.5 \mathrm{Kg})$ of leaf powder yielded $1 \mathrm{~g}$ of Nimbolide (Off-white solid).

Neem extract and nimbolide identification For identification of the extract, HPLC was done. The retention time (Rt) of standards (Azadirone, 28-Deoxonimbolide, Nimbolide, and Quercetin) were $4.980,3.548,2.971$, and 7.631 with100\% area. While the retention time (Rt) of Azadirone, 28-Deoxonimbolide, Nimbolide, and Quercetin in Ethanolic neem leaves extract, were found to be 5.191, 3.790, 2.912, and 7.77 respectively, which are matching with standards Rt values respectively. The amount of Azadirone, 28-Deoxonimbolide, Nimbolide, and Quercetin in Ethanolic neem leaves extract, were found to be $0.4 \%, 3.4 \%, 9.4 \%$ and $3.2 \% \mathrm{w} / \mathrm{v}$ respectively. To prove the structure of Nimbolide, it is cleared from Mass spectroscopy, $\mathrm{H}^{1} \mathrm{NMR}, \mathrm{C}^{13} \mathrm{NMR}$ as shown below

\section{M.S (EI): $\mathrm{m} / \mathrm{z}$ (\%) of nimbolide:}

Molecular weight $=466 \mathrm{~g} / \mathrm{mol}(\mathrm{M}+\cdot, 0.25), 402$ $\left(\mathrm{C}_{24} \mathrm{H}_{34} \mathrm{O}_{5}, 0.76\right), 385\left(\mathrm{C}_{22} \mathrm{H}_{25} \mathrm{O}_{5}, 14\right), 357\left(\mathrm{C}_{21} \mathrm{H}_{25} \mathrm{O}_{5}, 19\right)$, $314\left(\mathrm{C}_{19} \mathrm{H}_{22} \mathrm{O}_{4}, 9\right), 283\left(\mathrm{C}_{17} \mathrm{H}_{15} \mathrm{O}_{4}, 8\right), 267\left(\mathrm{C}_{15} \mathrm{H}_{23} \mathrm{O}_{4}, 6\right), 240$ $\left(\mathrm{C}_{15} \mathrm{H}_{12} \mathrm{O}_{3}, 4\right), 186\left(\mathrm{C}_{12} \mathrm{H}_{10} \mathrm{O}_{2}, 6\right), 126\left(\mathrm{C}_{7} \mathrm{H}_{10} \mathrm{O}_{2}, 9\right), 97\left(\mathrm{C}_{5} \mathrm{H}_{5} \mathrm{O}_{2}\right.$, 8), $59\left(\mathrm{C}_{2} \mathrm{H}_{3} \mathrm{O}_{2}, 3\right), 43\left(\mathrm{C}_{3} \mathrm{H}_{7}, 42\right)$.

\section{$\underline{H}^{1} \mathrm{NMR}$ (DMSO-d6, ppm) of nimbolide:}

$\delta=1.12\left(\mathrm{~s}, 3 \mathrm{H}, \mathrm{CH}_{3}-30\right), 1.28\left(\mathrm{~s}, 3 \mathrm{H}, \mathrm{CH}_{3}-19\right), 1.39(\mathrm{~s}, 3 \mathrm{H}$, $\left.\mathrm{CH}_{3}-29\right), 1.60\left(\mathrm{~s}, 3 \mathrm{H}, \mathrm{CH}_{3}-18\right), 2.00,1.96\left(\mathrm{~m}, 2 \mathrm{H}, \mathrm{C}_{16}-\mathrm{H}\right)$, 2.30, $3.10\left(\mathrm{dd}, 2 \mathrm{H}, \mathrm{C}_{11}-\mathrm{H}\right), 2.86\left(\mathrm{~d}, 1 \mathrm{H}, \mathrm{C}_{5}-\alpha \mathrm{H}\right), 3.36(\mathrm{~s}, 3 \mathrm{H}$, $\left.\mathrm{COCH}_{3}\right), 5.80\left(\mathrm{~d}, 1 \mathrm{H}, \mathrm{C}_{2}-\mathrm{H}\right), 6.23\left(\mathrm{~d}, 1 \mathrm{H}\right.$, furan- $\left.\mathrm{C}_{22}-\mathrm{H}\right)$, $7.27\left(\mathrm{~d}, 1 \mathrm{H}, \mathrm{C}_{3}-\mathrm{H}\right), 7.37\left(\mathrm{~s}, 1 \mathrm{H}\right.$, furan- $\left.\mathrm{C}_{21}-\mathrm{H}\right), 7.51(\mathrm{~d}, 1 \mathrm{H}$, furan- $\left.\mathrm{C}_{23}-\mathrm{H}\right)$.

\section{C13 NMR (DMSO-d6, ppm) of nimbolide:}

1. = $198.46(\mathrm{C}-1), 126.10(\mathrm{C}-2), 153.51(\mathrm{C}-3), 49.11(\mathrm{C}-4)$, 45.29 (C-5), 77.88 (C-6), 84.86 (C-7), 51.71(C-8), 39.84 (C9), 53.96 (C-10), 32.20 (C-11), 136.33 (C-13), 130.89 (C-14), 83.04 (C-15), 40.01 (C-16), 45.29 (C-17), 14.79 (C-18), 17.56
(C-19), 110.84, 125.32, 139.36, 143.84 (C-furan), 176.36 (C-28), $23.15(\mathrm{C}-29), 18.50(\mathrm{C}-30), 171.76(\mathrm{C}=\mathrm{O}$, acetate), 53.90 (CH3-acetate) (Fig. 1)

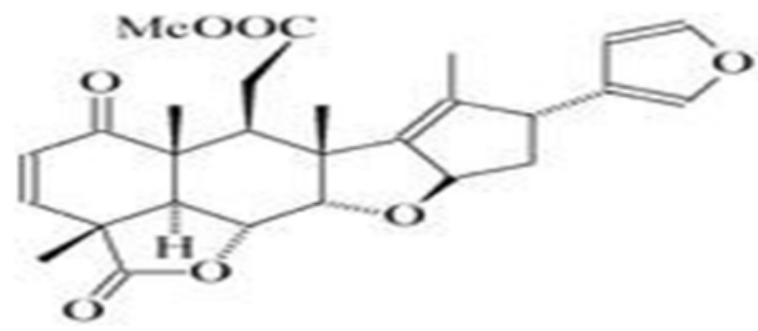

Figure 1. Structure of nimbolide Toxicity study and dose response curve.

For determination of median lethal dose (LD50) of ENLE, all doses up to $2000 \mathrm{mg} / \mathrm{Kg}$ mice were found to be nontoxic as no deaths were recorded which suggests that ENLE may be a safe mixture. For dose- response curve it is cleared that $5 \mathrm{mg}$ ENLE/Kg mice was found to be the most effective dose as it reduced the number of EAC cells in treated mice group to $76 \%$ of EAC cells compared with positive control mice group as shown in Fig. 2.

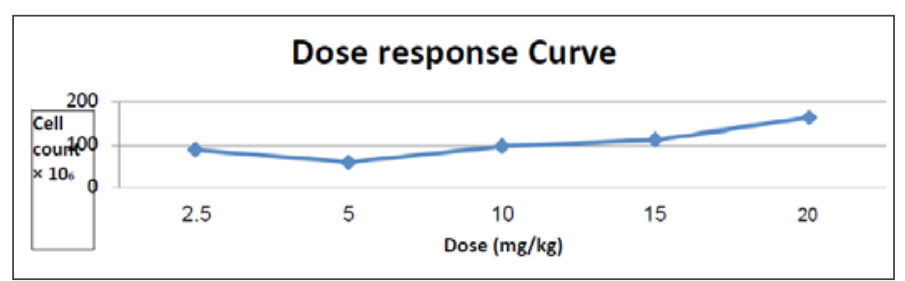

Figure 2. Dose response curve of total Neem extract.

\section{Viability and Life Span Prolongation}

From our results, it has been demonstrated that ENLE and nimbolide from neem leaves have display anticancer activity as they decreased EAC count in mice bearing EAC in all groups $(p<0.001)$ compared with positive control mice. Also both showed significant increase in life span in all studied groups compared with positive control group. See Table 1.

\section{Biochemical Investigations \\ Antioxidant Assay}

The effects of extracting and nimbolide have been tested on antioxidants. Data in Table 2 The results showed that the use of ethanol extract significantly reduced the levels of malondialdehyde (MDA) and nitric oxide (NO) $(p<0.001)$ in preventive groups and therapeutic. It also significantly increased the activity of catalase and lutathione and peroxidase enzymes in both treatment and preventive groups $(p<0.001)$. The results also showed that taking nempolid resulted in a significant reduction in levels of malondialdehyde (MDA) and nitric oxide (NO) $(p<0.001)$ in preventive groups and therapeutic. It also significantly increased the activity of catalase enzymes and asotathione peroxidase in both treatment and preventive groups $(p<0.001)$. 
Table 1. EAC count ( $\times 106$ cells $/ \mathrm{ml})$ and $\mathrm{T} / \mathrm{C} \%$ Among Different Study Groups

\begin{tabular}{l|c|c|c|c|c}
\hline \multicolumn{1}{c|}{ Group } & Positive control & \multicolumn{2}{c|}{ Nimbolide } & \multicolumn{2}{c}{ Extract } \\
\hline & & Therapeuti c Group & Preventiv e Group & Therapeuti c Group & Preventiv Groupe \\
\hline EAC count & $209.9 \pm 14.57$ & $48.6 \pm 1.8^{* * *}$ & No cells & $91.9 \pm 2.11^{* * *}$ & $68.4 \pm 1.95^{\star * *}$ \\
\hline Survival days & 9 & 14 & 15 & 16 & 17 \\
\hline life span T/C\% & - & $55.55 \%$ & $66.66 \%$ & $77.77 \%$ & $88.88 \%$ \\
\hline
\end{tabular}

Data are expressed as Means \pm SD. $(n=10)$.

N.S. $P$ value $>0.05$ was considered non-significant.

*P value $<0.05$ was considered significant.

${ }^{* *} \mathrm{P}$ value $<0.01$ was considered highly significant.

*** $P$ value $<0.001$ was considered very highly significant.

Table 2. Collective Table of Antioxidant Parameters Among Different Study Groups

\begin{tabular}{l|c|c|c|c}
\hline \multicolumn{1}{c|}{ Group } & MDA(nmol/ml) & NO(mmol/l) & Catalase(U/L) & Glutathione peroxidase(U/L) \\
\hline Negative control & $11.99 \pm 0.79^{*}$ & $19.84 \pm 1.11^{* * *}$ & $227.37 \pm 12.10^{* * *}$ & $200.37 \pm 4.63^{* * *}$ \\
\hline Positive control & $42.74 \pm 1.80$ & $34.42 \pm 3.33$ & $150.92 \pm 6.11$ & $102.44 \pm 3.48$ \\
\hline Therapeutic Nimbolide & $12.03 \pm 0.54^{* * *}$ & $13.27 \pm 1.91^{* * *}$ & $717.16 \pm 48.86^{* * *}$ & $614.48 \pm 19.53^{* * *}$ \\
\hline Preventive Nimbolide & $13 \pm 0.75^{* * *}$ & $18.21 \pm 1.38^{* * *}$ & $909.45 \pm 51.07^{* * *}$ & $773.41 \pm 62.73^{* * *}$ \\
\hline Therapeutic extract & $19.61 \pm 1.45^{* * *}$ & $22.97 \pm 1.24^{* *}$ & $353.38 \pm 35.60^{* * *}$ & $357.94 \pm 36.80^{* * *}$ \\
\hline Preventive extract & $14.04 \pm 0.37^{* * *}$ & $20.95 \pm 1.33^{* * *}$ & $454.08 \pm 68.19^{* * *}$ & $439.49 \pm 55.10^{* * *}$ \\
\hline
\end{tabular}

Data are expressed as Means \pm SD. $(n=10)$.

*P value $<0.05$ was considered significant.

** $\mathrm{P}$ value $<0.01$ was considered highly significant.

*** $\mathrm{P}$ value $<0.001$ was considered very highly significant. N.S. $\mathrm{P}$ value $>0.05$ was considered non-significant.

\section{Apoptotic Effect}

Data in Table 3 revealed that administration of the extract showed significant increase in caspase-3 activity and cytochrome $\mathrm{c}$ concentration in both therapeutic and preventive groups $(p<0.001)$. Also, nimbolide administration showed significant increase in caspase- 3 and cytochrome $c$ activities in therapeutic group $(p<0.001)$. While, in nimbolide preventive group the cells were absent.

\section{Liver function Tests}

The results from Table 4 showed that taking ENLE in mice has decreased AST in therapeutic $(\mathrm{P}>0.05)$ and preventive group $(p<0.001)$, ALT $(p<0.001)$ bilirubin levels and activities $(p<0.001)$ compared with positive control group but these values are within normal range in mice so that they showed insignificant change in these enzymes Data showed also insignificant increase in T.P $(p<0.05)$ and albumin activity $(p<0.05)$ compared with positive control and these values are within normal range after administration of extract. Also administration of nimbolide showed significant decrease in AST $(p<0.001)$ ALT $(p<0.001)$ and bilirubin $(p<0.001)$ compared with positive control group but these values are within normal range in mice so that they showed insignificant change in these enzymes. The results also showed a significant increase in levels of T.P $(p<0.001)$ and albumin activity $(p<0.001)$ compared with positive control and these values are within normal range after administration of nimbolide.

Table 3. Collective Table of Apoptosis Parameters Among Different Study Groups

\begin{tabular}{l|c|c}
\hline \multicolumn{1}{c|}{ Group } & Caspase-3(ng/ml) & (ng/ml)Cytochrome c \\
\hline Positive control & $0.834 \pm 0.06$ & $1.061 \pm 0.09$ \\
\hline Therapeutic Nimbolide & $3.462 \pm 0.22^{* * *}$ & $4.74 \pm 0.35^{\star * *}$ \\
\hline Therapeutic extract & $2.188 \pm 0.14^{* * *}$ & $2.48 \pm 0.28^{* * *}$ \\
\hline Preventive extract & $2.956 \pm 0.24^{* * *}$ & $3.32 \pm 0.36^{* * *}$ \\
\hline
\end{tabular}

Data are expressed as Means \pm SD. $(n=10)$.

N.S. $P$ value $>0.05$ was considered non significant

*P value $<0.05$ was considered significant.

**P value $<0.01$ was considered highly significant.

***P value $<0.001$ was considered very highly significant. 
Table 4. Collective Table of Liver Function Tests Among Different Study Groups

\begin{tabular}{|c|c|c|c|c|c|}
\hline Group & AST(U/L) & $\operatorname{ALT}(U / L)$ & Total protein(g/dl) & Albumin(g/dl) & Bilirubin(mg/dl) \\
\hline Negative Control & $81.3 \pm 2.36^{\star * *}$ & $41.5 \pm 2.33^{* * *}$ & $6.86 \pm 0.12^{\star \star *}$ & $2.63 \pm 0.11^{* * *}$ & $0.387 \pm 0.04^{\star * *}$ \\
\hline Positive control & $109.7 \pm 4.62$ & $113 \pm 8.07$ & $5.5 \pm 0.31$ & $1.78 \pm 0.16$ & $0.944 \pm 0.05$ \\
\hline Therapeutic Nimbolide & $55.2 \pm 2.71^{* * *}$ & $35.5 \pm 3.22^{* * *}$ & $6.91 \pm 0.13^{* * *}$ & $2.77 \pm 0.17^{* \star *}$ & $0.201 \pm 0.06^{* * *}$ \\
\hline Preventive Nimbolide & $41.7 \pm 5.17^{\star \star *}$ & $23.8 \pm 3.18^{\star * *}$ & $6.76 \pm 0.20$ & $2.82 \pm 0.13^{\star * *}$ & $0.138 \pm 0.05^{\star * *}$ \\
\hline Therapeutic extract & $102.8 \pm 7.99$ & $75.7 \pm 5.33^{* * *}$ & $5.85 \pm 0.32^{* *}$ & $2.21 \pm 0.14^{*}$ & $0.289 \pm 0.06^{* * *}$ \\
\hline Preventive extract & $84.5 \pm 3.38^{\star * *}$ & $73.5 \pm 4.43^{* * *}$ & $6.32 \pm 0.34^{*}$ & $2.23 \pm 0.12^{*}$ & $0.415 \pm 0.07^{\star * *}$ \\
\hline
\end{tabular}

Data are expressed as Means \pm SD. $(n=10)$.

N.S. $P$ value $>0.05$ was considered non significant (no stars)

${ }^{*} P$ value $<0.05$ was considered significant.

**P value $<0.01$ was considered highly significant.

$* * * P$ value $<0.001$ was considered very highly significant.

\section{Kidney Function Tests}

Our study showed that administration of ENLE had significant decrease effect on urea $(p<0.001)$ and creatinine activities $(p<0.001)$ in all studied groups and these values are within normal range. Also, administration of nimbolide showed significant decrease in urea $(p<0.001)$ and creatinine activities $(p<0.001)$ in all studied groups and these values are within normal range.

\section{Histopathological Examination}

After the study and the test group, the vital organs (liver and kidney). The microscope was carefully observed and did not reveal any significant lesions that could be observed when compared with the control group. Microscopic, the device detected some histological changes from the test groups when compared with the negative control group.

\section{Correlations Between Different Parameters in the Studied Groups}

To confirm our results, correlations between parameters in the studied groups were done, as there were positive and negative correlations between different parameters in the all studied groups. Among ENLE studied groups (Table 4), there were strong positive correlations between MDA and $\mathrm{NO}(\mathrm{r}=$ 0.95) $(p<0.01)$, GPx and (Catalase and Cytochrome c) $(r=0.9)$ and $(r=0.8)(p<0.01)$, Caspase-3 with (Cytochrome $\mathrm{c}$ and catalase) $(\mathrm{r}=0.97)$ and $(\mathrm{r}=0.84)(p$ $<0.01)$ and Catalase with cytochrome $\mathrm{c}(\mathrm{r}=0.82)(p$ $<0.01)$. Also there were strong negative correlations between MDA and (GPx and Catalase) ( $r=-0.6),(r=$ -0.6) $(p<0.01)$, NO and (GPx and Catalase) $(\mathrm{r}=-0.6)$ and $(\mathrm{r}=-0.6)(p<0.01)$. Among studied groups (Table $5)$, there were strong positive correlations between MDA and NO $(r=0.92)(p<0.01)$, GPx and (Catalase, Caspase- 3 and Cytochrome c) $(r=0.99),(r=0.95)$ and $(\mathrm{r}=0.97)(p<0.01)$ and Caspase with Cytochrome $\mathrm{c}$ $(\mathrm{r}=0.99)(p<0.01)$. Also there were strong negative correlations between MDA and (GPx and Catalase) $(\mathrm{r}=-0.6),(\mathrm{r}=-0.6)(p<0.01), \mathrm{NO}$ and $(\mathrm{GPx}$, Catalase, caspase- 3 and Cytochrome c) $(r=-0.7),(r=-0.7),(r=$ $-0.5)$ and $(r=-0.5)(p<0.01)$.

Table 5. Collective Table of Kidney Function Tests Among Different Study Groups

\begin{tabular}{l|c|c}
\hline \multicolumn{1}{c|}{ Group } & Urea(mg/dl) & Creatinine $(\mathrm{mg} / \mathrm{dl})$ \\
\hline Negative control & $21 \pm 3.97^{\star * *}$ & $0.385 \pm 0.17^{* * *}$ \\
\hline Positive control & $62.1 \pm 3.38$ & $1.663 \pm 0.16$ \\
\hline Therapeutic Nimbolide & $\star * * 24.9 \pm 2.21$ & $0 . .903 \pm 0.06^{\star * *}$ \\
\hline Preventive Nimbolide & $20.5 \pm 2.72^{\star * *}$ & $0.758 \pm 0.09^{\star * *}$ \\
\hline Therapeutic extract & $29.2 \pm 1.24^{\star * *}$ & $0.658 \pm 0.10^{\star * *}$ \\
\hline Preventive extract & $31.6 \pm 1.62^{\star * *}$ & $0.509 \pm 0.09^{\star * *}$ \\
\hline
\end{tabular}

Data are expressed as Means \pm SD. $(n=10)$.

N.S. $P$ value $>0.05$ was considered non-significant

${ }^{*} P$ value $<0.05$ was considered significant.

**P value $<0.01$ was considered highly significant.

*** $\mathrm{P}$ value $<0.001$ was considered very highly significant.

\section{Discussion}

Cancer is a word that expresses the term to describe a range of diseases that cause irregular growth, invasion, and the spread of (malignant tumor) of abnormal cells. Cancer occurs due to external factors such as malnutrition, environmental conditions, tobacco use, radiation, infectious organisms, lack of exercise, as well as internal factors such as mutations, genetics, and hormones. ${ }^{32}$ Neem leaf extracts have been reported to be non-mutagenic and non-toxic, and have been found to have immune, anti-cancer and antiinflammatory properties..$^{33}$ There are many studies that have shown that the extract of ethanol from neem leaves has an anti-cancer activity. Ethylene Neem Extract (ENLE) showed an anti-cancer activity against infectious carcinogenesis caused by nitrosoganidine and methane- $n \cdot{ }^{34}$ ENLE induces apoptosis in a-prostate cancer cell line (PC-3) by up-regulating the proapoptotic protein Bax and lessening the level of Bcl-2 
protein resulting In dividing the DNA into prostate cancer cells. ${ }^{35,36}$ Many biologically active compounds are isolated from this plant. Among them, nimbolide belongs to the lemongrass group. The main component of the neem leaves is Nimbolide, a tetrahydrate consisting of a lemon skeleton with an $\alpha, \beta$-unsaturated ketone system and a $\delta$-lactone ring. ${ }^{37}$ Nimbolide has many types of biological activity, including anti-cancer and anti-malarial activity. ${ }^{38}$ Nimbolide was obtained to have an anticancer activity in a wide range of cancer cells, including neuromuscular neural cell carcinoma, bone sarcoma, placental carcinoma, ${ }^{39,40}$ leukemia, ${ }^{41}$ and melanoma cells, and in macrophages ${ }^{41}$ ENLE contains several antioxidants and anticarcinogens including terpenoids, limonoids, quercetin and sitosterols. Neem leaf components such as nimbolide, 28-deoxonimbolide, and azadirone were obtained because they had a cytotoxic activity against different cancer cell lines. ${ }^{42}$ Quercetin, a neem bioflavonoid highly soluble in ethanol and potent antioxidants, was obtained to prevent the growth and regulation of cancer cells in malignant cell lines the expression of Bcl-2 and mutant p53 protein. ${ }^{43}$ 28-Deoxonimbolide exhibited potent cytotoxic activities against HL60 cells ${ }^{44}$ and showed high cytotoxicity against a normal lymphocyte cell line. ${ }^{45}$ LD50 of nimbolide was reported to be $225 \mathrm{mg} / \mathrm{Kg}$ body wt in mice according to ${ }^{13}$ unlike $^{46}$ who suggested that LD50 of nimbolide in amice was reported to be 280 $\mathrm{mg} / \mathrm{Kg}$ body wt. this difference was supposed to be due individual variation. ${ }^{47}$ The acute toxicity was estimated by intraperitoneal administration of the compounds (ENLE) to determine the median lethal dose (LD50). Our results revealed that, dose up to $2000 \mathrm{mg} / \mathrm{kg}$ was considered safe for ENLE. Our results showed that, 5 $\mathrm{mg} / \mathrm{kg}$ was considered to be the most effective dose of ENLE. Our results are in agreement with ${ }^{48}$ who reported that toxicological investigation of A. indica leaf extracts at $0.6-2.0 \mathrm{~g} / \mathrm{kg}$ body weight did not possess any lethal effects on hematology, enzyme levels and histopathological parameters of experimental animals. For the evaluation of antiproliferative activity of the ethanolic extract and nimbolide, it has been demonstrated that nimbolide and ENLE from neem tree have display anticancer activity as the decreased EAC count in mice in all treated groups. It showed $100 \%$ absence of tumor cells in nimbolide preventive group. ENLE has helped reduce cell proliferation by inhibiting an insulin-like growth factor (IGF) signaling molecules MCF-7 and MDA MB-231. ${ }^{49}$ In another study, the antidepressant activity of the ENLE extract alone or in combination with cisplatin was demonstrated by a cell survival test on human breast $(\mathrm{MCF}-7)$ and cervical human epithelial adenocarcinoma cell line (HeLa) cancer cells. ${ }^{50}$ The therapeutic dose was found to be $22.5 \mathrm{mg} / \mathrm{Kg}$ b.w. which is one tenth of the LD50 and the effective dose according to ${ }^{14}$ who reported that administration of nimbolide at $20 \mathrm{mg} / \mathrm{kg}$ of body weight reduced tumor growth by almost $90 \%$ of human colorectal cancer xenografts which supports our results. Nimbolide has effectively inhibited proliferation of WiDr colon cancer cells and has been shown to exert its antiproliferative effects in various cell lines. ${ }^{51}$ Also, ${ }^{38}$ suggested that Nimbolide, a triterpenoid extracted from the flowers of the neem tree (Azadirachta indica), was found to have antiproliferative activity against some cancer cell lines resulted in cell cycle disruption Living organisms possess intrinsic antioxidant defense mechanisms against free radicals, which are sufficient to prevent oxygen radical cytotoxic effects. ${ }^{52}$ In our study MDA, NO and other major antioxidants were chosen as lipid peroxidation indicators. Our results showed significant decrease in MDA and NO levels while it showed increase in the activities of catalase and glutathione peroxidase. Hence, it may be possible that ENLE and nimbolide decrease lipid peroxidation level due to their antioxidant effect. Our results agreed with $^{53}$ who suggested that Neem leaf aqueous extract, flower and stem bark ethanol extracts exhibited higher free radical scavenging. The leaf aqueous extract is significantly decreased malondialdehyde (MDA) levels by the thiobarbituric acid reactive substances (TBARS) method for cure of diabetes. Another study showed an increase in MDA and NO levels after treatment with methanolic leaves extract of Azadirachta indica (MLEN, $500 \mathrm{mg} / \mathrm{Kg}$ b.w) on cisplatin- (CP) induced nephrotoxicity and oxidative stress in rats. However, the oral administration of MLEN to CP-intoxicated rats for 5 days brought back MDA, NO production, and enzymatic and non-enzymatic antioxidants to near normalcy ${ }^{54} \mathrm{~A}$. indica (neem) leaf extract has been shown to enhance the activity of GPx in various tissues of mice and rats. ${ }^{55}$ Another study showed that A. indica leaf extract elevated GPx activity in benzo (a)pyreneinduced forestomach tumorigenesis in mice. ${ }^{56} \mathrm{GPx}$ activity was significantly increased in the stomach after treatment with ethanolic neem leaf extract against $\mathrm{N}$-methyl - $\mathrm{N}^{\prime}-$ nitro-N nitrosoguanidine-induced Gastric Carcinogenesis in Wistar Rats. ${ }^{33}$ This may be may be attributed to enhanced antioxidant capacities. Increased generation of ROS such as $\mathrm{O}_{2}{ }^{--}$and $\mathrm{H}_{2} \mathrm{O}_{2}$ is recognized to induce $\mathrm{CT}$ and GPx. Higher activities of antioxidant enzymes have been observed in malignant tumors compared with control. ${ }^{57}$ Apoptosis is an ordered and orchestrated cellular operation that occurs in physiological and pathological conditions. Apoptosis plays an important role in the treatment of cancer as it is a popular target of many treatment strategies. ${ }^{58}$ Caspase-3 is also required for some typical hallmarks of apoptosis. ${ }^{59}$ Cytochrome $\mathrm{c}$ is also involved in initiation of apoptosis. Upon release of cytochrome c to the cytoplasm, the protein binds apoptotic protease activating factor. ${ }^{60}$ Cytochrome $c$ was reported to be higher in cancer tissues than in non-diseased organs. ${ }^{61}$ Our results showed significant increase in Caspas-3 activity and Cytochrome c level compared with positive control group. ${ }^{62}$ investigated that nimbolide; a limonoid 
present in leaves and flowers of the neem tree (Azadirachta indica) activates caspase 3. Also, the mitochondrial pathway is engaged by the release of apoptogenic factors like cytochrome $\mathrm{c}$ from the mitochondrial inter membrane space into the cytosol. Results In vivo showed that NLE treatment induced morphological apoptotic changes were associated with increased caspase 3 in oocyte. ${ }^{63}$ Also, our study is in agreement with ${ }^{64}$ who reported that nimbolide increase Cytochrome c levels while treating human colon cancer cells with neem extract and suggested that Cytochrome $\mathrm{c}$ is a controlled form of cell death used to kill cells in the process of development or in response to infection or DNA damage. Liver is the most important key organ in the metabolism, detoxification and secretary functions in the body and it is highly affected primarily by toxic agents thus the following parameters were studied for assessment of the liver damage: Aspartate aminotransferase (AST), Alanine aminotransferase (ALT), Total protein (T.P), Albumin (Alb) and Bilirubin. ${ }^{65}$ Our study showed that ethanolic neem leaves extract and nimbolide showed insignificant changes in all parameters in the studied groups which prove the nonhepatotoxic nature of neem according to normal values reported in. ${ }^{66}$ The non-hepatotoxic nature of neem was proved in the study performed by ${ }^{67}$ who was found unaltered and normal activities of serum ALT and AST following prophylactic treatment on Swiss albino mice with neem leaf preparation against Ehrlich's carcinoma. Also, ${ }^{68}$ reported the hepatoprotective role of neem leaves extract against paracetamol-induced hepatic damage in albino rats as indicated by stable serum activity of ALT and AST and histopathological observations of liver tissues. Similarly, Azadirachta Indica (Neem) aqueous leaf extract significantly prevented changes in the serum levels of bilirubin, total protein, alanine aminotransferase, aspartate aminotransferase after induction with antitubercular drugs in albino rats. ${ }^{69}$ The kidneys are important because they keep the composition, or make up, of the blood stable, which lets the body functions like: prevent the buildup of wastes and extra fluid in the body, keep levels of electrolytes stable, such as sodium, potassium, and phosphate, make hormones that help, regulate blood pressure, make red blood cells and bones stay intensive. ${ }^{70}$ Our results showed insignificant decrease in Urea and Creatinine levels with respect to positive control group and these values are within normal values according to ${ }^{66,71}$ reported that neem leaf glycoprotein (NLGP) is non-toxic even in higher doses and showed apparently normal urea and creatinine levels. Thus, it can be recommended for human use in anti-cancer therapy. Another study investigated the protective effect of Azadirachta indica (neem) leaves against cisplatin induced nephrotoxicity. Neem leaves showed significant protection as evidenced by the decrease of elevated urea. This improvement of physiological function was associated with high protection against histopathological injury induced by cisplatin on kidney. This result suggests that neem leaves pre; co and post-treatment can prevent the nephrotoxicity induced by cisplatin. ${ }^{72}$ This was in accordance with another study which reported insignificant change in urea and creatinine of aqueous Azadirachta indica leaf extract (ALE) as a study for the performance serum biochemistry parameters of broiler chicks. ${ }^{73}$ The gold standard for diagnosis and staging of much diseases is histopathology. Histopathology refers to the microscopic examination of tissue to study the manifestations of disease specifically, in clinical medicine. ${ }^{74}$ The livers of the positive group showed very clear pathological changes, such as focal large area of necrotic cells and infiltrated with mononuclear cells while the negative control group showed normal healthy hepatic parenchyma. The therapeutic and the preventive groups of Nimbolide and ENLE also showed normal healthy hepatic parenchyma as shown in Figs. $3 \mathrm{a}, 3 \mathrm{~b}, 3 \mathrm{c}$ and $3 \mathrm{~d}$. The kidneys of the positive group showed very clear pathological changes, such as mononuclear cells infiltration while the negative group showed normal glomeruli and renal tubules. The therapeutic and the preventive groups of Nimbolide and ENLE also showed normal glomeruli and renal tubules as shown in Figs. 4a, 4b, 4c, and 4d. It was found that histopathological changes were remarkably reversed in graded doses of nimbolide pretreated rats with lesser vacuolar degeneration and hepatic necrosis. Our results are in accordance with ${ }^{65}$ who reported that nimbolide protected the liver tissue against $\mathrm{CCl}_{4}$ toxicity with mild hepatocellular degeneration, less inflammatory cell infiltration and well preserved hepatocytes were observed in most areas and the recovery from degeneration of hepatic cells of nimbolide pretreated were comparable to that of standard Silymarin. Paracetamol induced liver necrosis was found to be reduced as observed macroscopically and histologically after treating with aqueous leaf extract of Azadirachta indica (A. indica) ${ }^{68}$ To confirm our results, correlations between parameters in the studied groups were calculated, as there were positive and negative correlations between different parameters in the all studied groups. In conclusion, the present study demonstrated that ethanolic neem leaves extract and nimbolide provided a significant antiproliferative activity against Ehrlich ascites carcinoma cells and had potent antioxidant activity and good inducer for apoptosis by stimulation of caspase- 3 and releasing of cytochrome $\mathrm{c}$ with no side effects on liver or kidney.

Also, the present study demonstrated that nimbolide provided a significant protective effect against Ehrlich ascites when administered as it showed 100\% absence of tumor cells. The anticancer activity of nimbolide could be due to presence of $\alpha, \beta$-unsaturated ketone structural element and $\delta$-lactone ring so, suggests that nimbolide represent a high potential for antitumor activity than neem extract. 

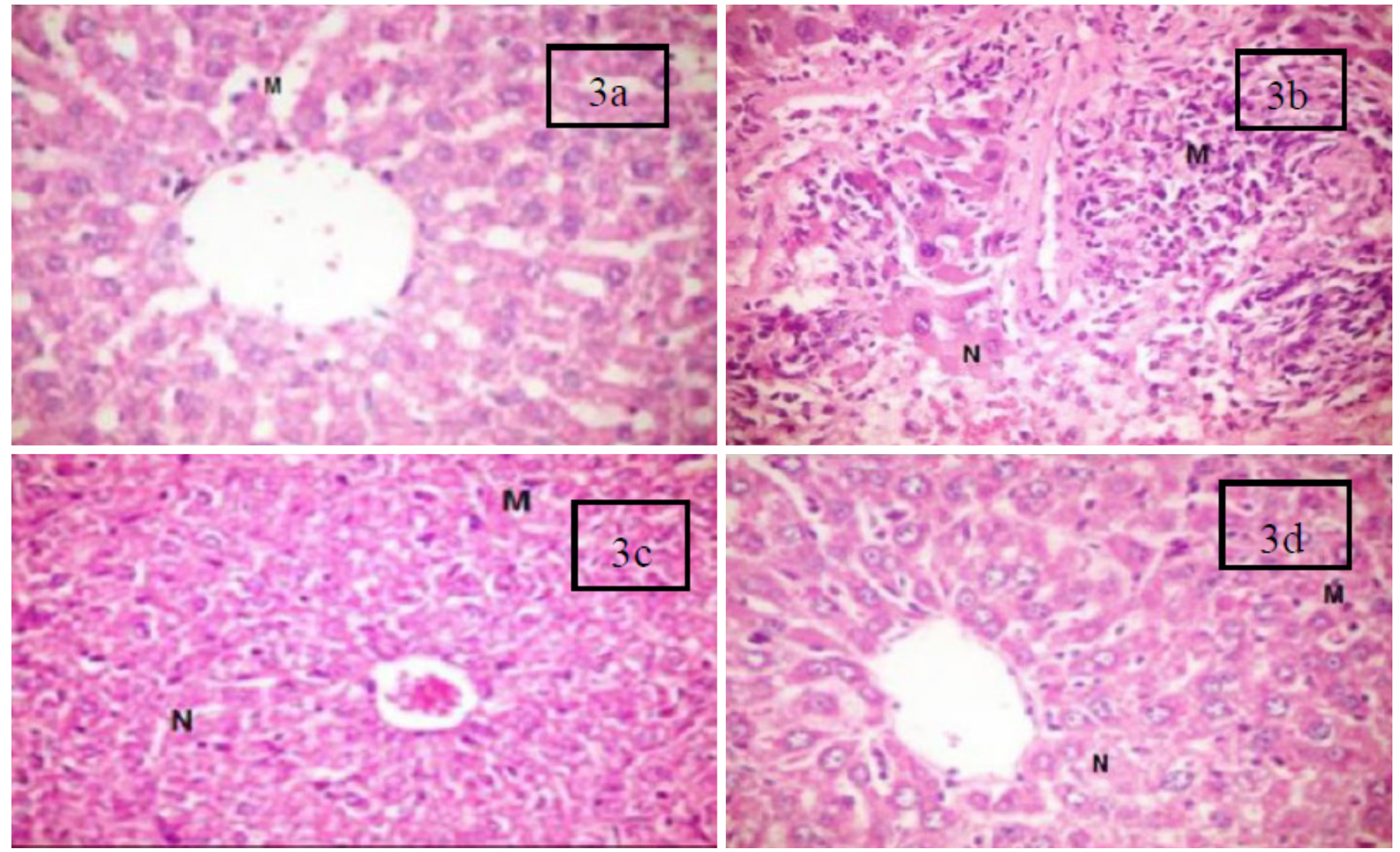

Figure 3. (a): A photomicrograph of Liver "Negative Control Group" showing normal healthy hepatic parenchyma and (b): A photomicrograph of Liver "Positive Control Group" showing focal large area of necrotic cells [N] infiltrated with mononuclear cells [M] (Hx\& E X400). (c): A photomicrograph of liver "Extract preventive and therapeutic Groups" showing healthy hepatic parenchyma while (d): A photomicrograph of liver"Nimbolide preventive and therapeutic Groups" showing healthy hepatic parenchyma. (Hx\& E X400).
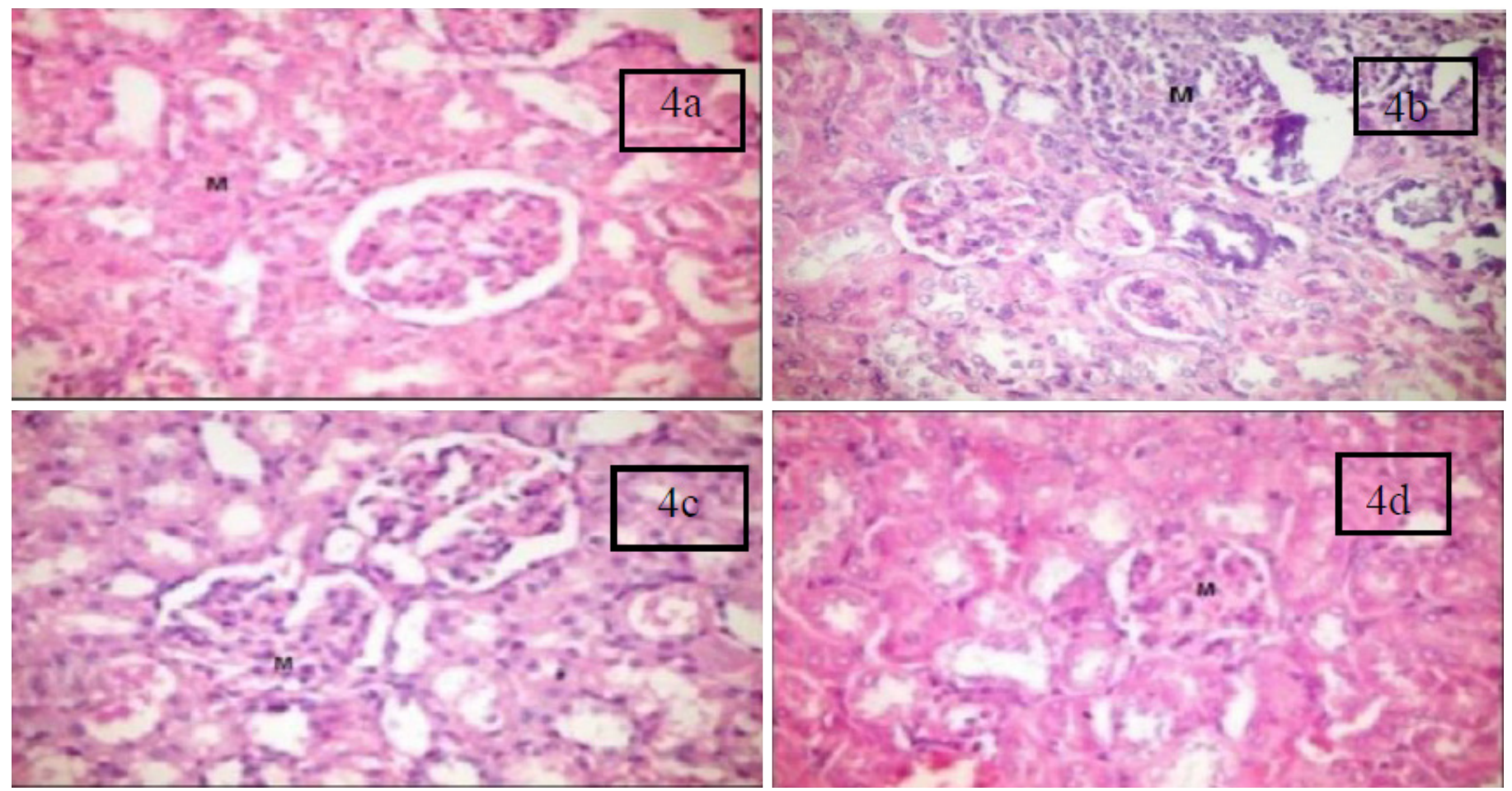

Figure 4. (a): A photomicrograph of kidney "Negative control Group" showing normal glomeruli and renal tubules and (b): A photomicrograph of kidney "Positive control Group" showing mononuclear cells infiltration [M]. (Hx\& E X400). (c): A photomicrograph of kidney "Extract preventive and therapeutic Groups" showing normal glomeruli and renal tubules while (d): A photomicrograph of kidney "Nimbolide preventive and therapeutic Groups" showing normal glomeruli and renal tubules. (Hx\& E X400). 


\section{References}

1. David Sc. (2015). Causes of Cancer. 25(3), p145-216.

2. Schumacker PT. Reactive oxygen species in cancer: a dance with the devil. Cancer Cell 2015;27(2):156-157 10.1016/j.ccell.2015.01.00 PubMed. 3. Basu AK. DNA Damage, Mutagenesis and Cancer. Int J Mol Sci 2018;19(4):970 10.3390/ijms19040970 PubMed.

4. Maha G, Bhuvaneshwari V, Amsaven R, Ragavendran P, Kalaiselvi M. Antioxidant and antibacterial activity from whole plant of Eclipta Alba (l.)- an in vitro model. International Journal of Biosciences and Nanosciences. 2015;2(1):1-8 http://www.ijbsans.com/archives/ journal15/jan15/MS-15-102.pdf.

5. Azman NA, Gallego MG, Juliá L, Fajari L, Almajano M. The Effect of Convolvulus arvensis Dried Extract as a Potential Antioxidant in Food Models. Antioxidants 2015;4(1):170-184 PubMed.

6.Nawal K. (2015). Plants as a Source of Natural Antioxidants. CABI; 1 edition (February 20, 2015).

7. Yogesh W, Ranjit R, Aparna S. Review on Biological Activities of Azadirachta. International Journal of Informative \& Futuristic Research. 2015;2(5):1327-1334 https://www.researchgate.net/ publication/282856855_Review_On_Biological_Activities_Of_ Azadirachta_Indica_Neem_and_its_Medicinal_Uses.

8. Chattopadhyay RR. Possible biochemical mode of anti-inflamtory action of Azadirachta indica A. Juss. in rats. Indian J Exp Biol 1998;36 (4):418-420 https://books.google.com.eg/books?id=Q-0a6SXDKB0C\& $p g=P A 143 \& l p g=P A 143 \& d q=$ Possible + biochemical + mode + of + antiinflammatory+action+of+Azadirachta+indica+A.Juss+in+rats.+Indian $+J+E x p+B i o l,+36,+41820 . \&$ source $=b l \& o t s=m 1 x q 3 Y 2 d-$ $w r \& s i g=A C f U 3 U 1 g e S w g V 0 X A u C 6 m U 3 V U B z c b 7 X 3 t s A \& h l=a r \& s a=X-$ \&ved=2ahUKEwiZ5oeDvp7hAhVQzBoKHX56CHcQ6AEwCXoECAkQA$Q \# v=$ onepage $\& q=$ Possible $\% 20$ biochemical $\% 20$ mode $\% 20$ of $\% 20$ antiinflammatory\%20action\%20 of\%20Azadirachta\%20indica\%20A. Juss\%20in\%20rats.\%20Indian\%20J\%20Exp\%20Biol\%2C\%2036\%2C\%20 418-20.\&f=false PubMed.

9. Subapriya R, Bhuvaneswari V, Ramesh V, Nagini S. Ethanolic leaf extract of neem (Azadirachta indica) inhibits buccal pouch carcinogenesis in hamsters. Cell Biochem Funct 2005;23(4):229-238 PubMed. $<j r n>$.

10. Sutthatip M, Chalerm S. Isolation and Structure Modification of Biologically Active Compound Nimbolide from Azadiracthta indica A. Juss. Var. siamensis Valeton. NUJ 2003;11(3): 45-49. (http:// www.thaiscience.info/journals/Article/NUJ/10440939.pdf).

11. Fahim FA, Esmat AY, Mady EA, Amin MA. Serum LDH and ALP isozyme activities in mice bearing solid Ehrlich carcinoma and/or treated with the maximum tolerated dose (MTD) of aloin. Dis Markers 1997;13(3):183-193 http://europepmc.org/abstract/med/9405931 PubMed.

12. Meier J, Theakston RDG. Approximate LD50 determinations of snake venoms using eight to ten experimental animals. Toxicon 1986;24(4):395-401 PubMed.

13. Crump K.S., Hoel D.G., Langley C.H., Peto R. Fundamental Carcinogenic Processes and Their Implications for Low Dose Risk Assessment. Cancer Res 1976;36 (9_Part1): 2973-2979.

14. Rojanapo W, Suwanno S, Somjaree R, Glinsukon T, Thebtaranont Y. Mutagenic and antibacterial activity testing of nimbolide and nimbicacid. J Sci Soc Thailand 1985;11:177-181</jrn>

15. Gupta SC, Prasad S, Sethumadhavan DR, Nair MS, Mo YY, Aggarwal BB. Nimbolide, a limonoid triterpene, inhibits growth of human colorectal cancer xenografts by suppressing the proinflammatory microenvironment. Clin Cancer Res 2013;19(16):4465-4476 PubMed. 16. McLIMANS WF, Davis EV, Glover FL, Rake GW. The submerged culture of mammalian cells; the spinner culture. J Immunol 1957;79(5):428433 https://www.ncbi.nlm.nih.gov/pubmed/13491853 PubMed.

17. Mazumdar UK, Gupta M, Maiti S, Mukherjee D. Antitumor activity of Hygrophila spinosa on Ehrlich ascites carcinoma and sarcoma-180 induced mice. Indian J Exp Biol 1997;35(5):473-477 https://www.ncbi. nlm.nih.gov/pubmed/9378516 PubMed.

18. Satoh K. Serum lipid peroxide in cerebrovascular disorders determined by a new colorimetric method. Clin Chim Acta 1978;90(1):37-43 PubMed.

19.Montgomery HC, Dymock JF. The determination of nitrite in wa- ter. Analyst (Lond) 1961;86:414-416 http://www.sciepub.com/reference/81876.

20. Aebi H. Catalase in vitro. Methods Enzymol 1984;105:121-126. 21. Paglia DE, Valentine WN. Studies on the quantitative and qualitative characterization of erythrocyte glutathione peroxidase. J Lab Clin Med 1967;70(1):158-169 https://www.ncbi.nlm.nih.gov/pubmed/6066618 PubMed.

22. Casciola-R L, Nicholson DW, Chong T, et al. Apopain/CPP32 cleaves proteins that are essential for cellular repair: a fundamental principle of apoptotic death. J Exp Med 1996;1996:183 https://www.ncbi. nlm.nih.gov/pubmed/8642305.

23. Cai J, Yang J, Jones DP. Mitochondrial control of apoptosis: the role of cytochrome c. Biochim Biophys Acta 1998;1366(1-2):139-149 PubMed.

24. Doumas BT, Bayse DD, Carter RJ, et al. candidate reference method for determination of total proteins in serum. I. Development and validation, II. Tests for transferability. Clin Chem 1981;27:16421654 https://webcache.googleusercontent.com/search?q=cache:x9ZfgY2AC9IJ:https://pdfs.semanticscholar.org/58f1/202ce6f32bace $888185155980 d 4 d 2 b 1 f 3 b 50 . p d f+\& c d=1 \& h l=a r \& c t=c l n k \& g l=e g$ PubMed.

25. Doumas BT, Watson WA, Biggs HG. Albumin standards and the measurement of serum albumin with bromcresol green. Clin Chim Acta 1971;31(1):87-96 PubMed.

26. Reitman S, Frankel S. A colorimetric method for the determination of serum glutamic oxalacetic and glutamic pyruvic transaminases. Am J Clin Pathol 1957;28(1):56-63 PubMed.

27. Jendrassik L, Grof P. Biochem. 1938;7297:81.

28. Chaney AL, Marbach EP. Modified reagents for determination of urea and ammonia. Clin Chem 1962;8(130):130-132 PubMed.

29. Murray RL. Creatinine, Kaplan A (1984). Clinical Chemistry. The C.v. Mosby Co. St.Louis. Toronto. Princeton, p 1261-1266 and 418.

30. Lillie RD. Histopathologic technique. Practical Histochemistry. 1976;95:851-859.

31.Levesque R. (2007): Programming and Data Management: A Guide for SPSS and SAS Users, Fourth Edition, SPSS Inc., Chicago Ill.

32. Peter C. (2008). What Is Cancer? Medical News Today.

33. Subapriya R, Nagini S. Medicinal properties of neem leaves: a review. Curr Med Chem Anticancer Agents 2005;5(2):149-6 PubMe.

'34. Subapriya R, Nagini S. Ethanolic neem leaf extract protects against $\mathrm{N}$-methyl - $\mathrm{N}$ '-nitro- $\mathrm{N}$-nitrosoguanidine-induced gastric carcinogenesis in Wistar rats. Asian Pac J Cancer Prev 2003;4(3):215-223 PubMed.

35. Kumar S, Suresh PK, Vijayababu MR, Arunkumar A, Arunakaran J. Anticancer effects of ethanolic neem leaf extract on prostate cancer cell line (PC-3). J Ethnopharmacol 2006;105(1-2):246-250 PubMed 6. Gunadharini DN, Elumalai P, Arunkumar R, Senthilkumar K, Arunakaran J. Induction of apoptosis and inhibition of PI3K/Akt pathway in PC-3 and LNCaP prostate cancer cells by ethanolic neem leaf extract. J Ethnopharmacol 2011;134(3):644-650 PubMed.

37. Anitha G, Raj JJ, Krishnan VR, Narasimhan S, Solomon KA, Rajan SS. Semi-synthetic modification of nimbolide to 6-homodesacetylnimbin and 6-desacetylnimbin and their cytotoxic studies. J Asian Nat Prod Res 2007;9(1):73-78 PubMed.

38. Roy MK, Kobori M, Takenaka M, et al. Antiproliferative effect on human cancer cell lines after treatment with nimbolide extracted from an edible part of the neem tree (Azadirachta indica). Phytother Res 2007;21(3):245-250 PubMed.

39. Phillips DR, Rasbery JM, Bartel B, Matsuda SP. Biosynthetic diversity in plant triterpene cyclization. Curr Opin Plant Biol 2006;9(3):305314 PubMed.

40. Gerhauser C. Cancer chemopreventive potential of apples, apple juice, and apple components. Planta Med 2008;74(13):1608-1624 PubMed $</$ jrn $>$

41. Neto CC. Cranberry and its phytochemicals: a review of in vitro anticancer studies. J Nutr 2007; 137(1, Suppl)186S-193S PubMed</jrn> 42. Nanduri S, Thunuguntla SSR, Nyavanandi VK, et al. Biological investigation and structure-activity relationship studies on azadirone from Azadirachta indica A. Juss. Bioorg Med Chem Lett 
2003;13(22):4111-4115 PubMed.

43. Nguyen TT, Tran E, Nguyen TH, Do PT, Huynh TH, Huynh H. The role of activated MEK-ERK pathway in quercetin-induced growth inhibition and apoptosis in A549 lung cancer cells. Carcinogenesis 2004;25(5):647-659 PubMed.

44. Kikuchi T, Ishii K, Noto T, et al. Cytotoxic and apoptosis-inducing activities of limonoids from the seeds of Azadirachta indica (neem). J Nat Prod 2011;74(4):866-870 PubMed.

45. Pati HN, Das U, Kawase $M$, et al. 1-Aryl-2-dimethylaminomethyl-2-propen-1-one hydrochlorides and related adducts: A quest for selective cytotoxicity for malignant cells. Bioorg Med Chem 2008;16(10):5747-5753 PubMed.

46. Glinsukon T, Somjaree R, Piyachaturawat $P$, Thebtaranonth $Y$. Acute toxicity of nimbolide and nimbic acid in mice, rats and hamsters. Toxicol Lett 1986;30(2):159-166 PubMed.

47. Elizabeth Casarez. (2001). Basic Prinicples of Toxicology. BIOC 597C January 10. (http://www.chymist.com/Toxicology\%20notes.pdf).

48. Ghimeray AK, Jin C, Ghimire BK, Cho DH. Antioxidant activity and quantitative estimation of azadirachtin and nimbin in Azadirachta IndicaA. Juss grown in foothills of Nepal. Afri J Biol. 2009;8:3084-3091. 49. Perumal E, Dharmalingam N G,Kalimuthu S, Sivanantham B, Ramachandran A, Chellakkan S enson, Govindaraj Sh and Jagadeesan A.(2012). Ethanolic neem (Azadirachta indica A. Juss) leaf extract induces apoptosis and inhibits the IGF signaling pathway in breast cancer cell lines. 2(1), January-March 2012, Pages 59-68.

50. Chhavi Sh, Andrea J. Vas P.G, Taher M. Gh, Tahir A. R, and Arif H. (2014). Ethanolic Neem (Azadirachta indica) Leaf Extract Prevents Growth of MCF-7 and HeLa Cells and Potentiates the Therapeutic Index of Cisplatin. Journal of Oncology. (2014), 10 pages.

51. Babykutty S, S PP, J NR, et al. Nimbolide retards tumor cell migration, invasion, and angiogenesis by downregulating MMP-2/9 expression via inhibiting ERK1/2 and reducing DNA-binding activity of NF-KB in colon cancer cells. Mol Carcinog 2012;51(6):475-490 PubMed.

52. Toshikazu Y, Yuji N. What Is Oxidative Stress? JMAJ 2002;45(7): 271276, (http://www.med.or.jp/english/pdf/2002_07/271_276.pdf.

53. Moumita D, Utpal R, Runu Ch. And Debasish M. Role of diet and plants on diabetic patients- A critical appraisal. Sci Cult 2011; ; *:77. 54. Ahmed E, Mohamed S, Ahmed M. (2014). Azadirachta indica Attenuates Cisplatin-Induced Nephrotoxicity and Oxidative Stress. BRI. Volume 2014.

55. Dasgupta T, Banerjee S, Yadava PK, Rao AR. Chemopreventive potential of Azadirachta indica (Neem) leaf extract in murine carcinogenesis model systems. J Ethnopharmacol 2004;92(1):23-36 PubMed. 56. Gangar SC, Sandhir R, Rai DV, Koul A. Modulatory effects of Azadirachta indica on benzo(a)pyrene-induced forestomach tumorigenesis in mice. World J Gastroenterol 2006;12(17):2749-2755 PubMed. 57. Kumaraguruparan R, Subapriya R, Viswanathan P, Nagini S. Tissue lipid peroxidation and antioxidant status in patients with adenocarcinoma of the breast. Clin Chim Acta 2002;325(1-2):165-170 PubMed. 58. Wong RS. Apoptosis in cancer: from pathogenesis to treatment. J Exp Clin Cancer Res 2011;30:87 PubMed.

59. Porter AG, Jänicke RU. Emerging roles of caspase-3 in apoptosis. Cell Death Differ 1999;6(2):99-104 PubMed.

60. Tafani M, Karpinich NO, Hurster KA, et al. Cytochrome c release upon Fas receptor activation depends on translocation of full-length bid and the induction of the mitochondrial permeability transition. J Biol Chem 2002;277(12):10073-10082 PubMed.

61. Sánchez-Alcázar JA, Ault JG, Khodjakov A, Schneider E. Increased mitochondrial cytochrome c levels and mitochondrial hyperpolarization precede camptothecin-induced apoptosis in Jurkat cells. Cell Death Differ 2000;7(11):1090-1100 PubMed.

62. Elumalai P, Gunadharini DN, Senthilkumar K, et al. Induction of apoptosis in human breast cancer cells by nimbolide through extrinsic and intrinsic pathway. Toxicol Lett 2012;215(2):131-142 PubMed. 63. Anima T, Tulsidas G. Shrivastav and Shail K. Chaube. Aqueous extract of Azadirachta indica (neem) leaf induces generation of reactive oxygen species and mitochondria-mediated apoptosis in rat oocytes. J Assist Reprod Genet. 2011;29:15-23. (https://www.ncbi.nlm.nih.gov/ pmc/articles/PMC3252410/).

64. Gupta SC, Reuter S, Phromnoi K, et al. Nimbolide sensitizes human colon cancer cells to TRAIL through reactive oxygen species- and ERK-dependent up-regulation of death receptors, p53, and Bax. J Biol Chem 2011;286(2):1134-1146 10.1074/jbc.M110.191379 PubMed.

65. Nagappa SB, Ravindranath HA, Mukhtar A, Murigendra BH. Evaluation of acute toxicity of neem active constituent, Nimbolide and its hepatoprotective activity against acute dose of carbon tetrachloride treated albino rats. IJPSR 2014;5(8): 3455-3466. (http:// ijpsr.com/bft-article/evaluation-of-acute-toxicity-of-neem-active-constituent-nimbolide-and-its-hepatoprotective-activity-against-acute-dose-of-carbon-tetrachloride-treated-albino-rats/?view=fulltext).

66. http:// www.ahc.umn.edu/rar/refvalues.html.

67. Haque E, Mandal I, Pal S, Baral R. Prophylactic dose of neem (Azadirachta indica) leaf preparation restricting murine tumor growth is nontoxic, hematostimulatory and immunostimulatory. Immunopharmacol Immunotoxicol 2006;28(1):33-50 PubMed</jrn>

68. Bhanwra S, Singh J, Khosla P. Effect of Azadirachta indica (Neem) leaf aqueous extract on paracetamol-induced liver damage in rats. Indian J Physiol Pharmacol 2000;44(1):64-68 https:// www.semanticscholar.org/paper/Effect-of-Azadirachta-indica-(Neem)-leaf-aqueous-on-Bhanwra-Singh/4998b0e47748f4bc1f8ed136cb328ea990afb058 PubMed.

69. Kale BP, Kothekar MA, Tayade HP, Jaju JB, Mateenuddin M. Effect of aqueous extract of Azadirachta Indica leaves on hepatotoxicity induced by antitubercular drugs in rats. Indian J Pharmacol 2003;35:177180 http://medind.nic.in/ibi/t03/i3/ibit03i3p177.pdf</jrn>

70. Schluster VL, Seldin DW. (2004). Renal clearance. In: Seldin DW, Giebisch G, Eds. The Kidney: Physiology and Pathology of New York: Raven Press; 1985, PP. 365-395.

71. Mallick A, Ghosh S, Banerjee S, Majumder S, Das A, et al. Neem leaf glycoprotein is nontoxic to physiological functions of Swiss mice and Sprague Dawley rats: histological, biochemical and immunological perspectives. Int Immunopharmacol 2013;15(1):73-83 PubMed.

72. Doaa E-D, Mohamed SG, Abdel Razik HF, Ahmed EAM. Physiological and histological impact of Azadirachta indica (neem) leaves extract in a rat model of cisplatin-induced hepato and nephrotoxicity. J Med Plants Res 2011;5(23):5499-5506 https://www.researchgate.net/publication/216069615_Physiological_and_histological_impact_of_Azadirachta_indica_neem_leaves_extract_in_a_rat_model_of_cisplatin-induced_hepato_and_nephrotoxicity.

$<$ unknown $>73$. Onu P., Aniebo A. (2013). Toxicity and nutritional assessment of aqueous Azadirachta indica (neem) leaf extract in broiler chicks. 3(6), p. 172-180.

74. Brown MV, MCDunn JE, Gunst PR, et al. Cancer detection and biopsy classification using concurrent histopathological and metabolomic analysis of core biopsies. Genome Med 2012;4(4):33 PubMed.
Received: April 6, 2019

Accepted: July 23, 2019
Corresponding author

Mohamed Abd El-Hakim Basuni

Email: e-mail: mohamed_0020@yahoo.com 